\title{
Synthesis and pharmacological evaluation of 7-substituted 1-ethyl- 3,4,10-trimethyl-1,10-dihydro-11H-pyrazolo[3,4-c][1,6] benzodiazocin-11-one. A new ring system
}

\author{
Onofrio Migliara ${ }^{a^{*},}$ Salvatore Plescia ${ }^{a}$, Patrizia Diana ${ }^{b}$, Vita Di Stefano ${ }^{a}$, \\ Lorenzo Camarda ${ }^{a}$, and Roberta Dall'Olio ${ }^{c}$ \\ ${ }^{a}$ Dipartimento di Chimica e Tecnologie Farmaceutiche, Università di Palermo, Via Archirafi 32, \\ 90123 Palermo, Italy \\ ${ }^{b}$ Dipartimento Farmacochimico, Tossicologico e Biologico, Università di Palermo, Via \\ Archirafi 32, 90123 Palermo, Italy \\ ${ }^{c}$ Dipartimento di Farmacologia, Università di Bologna, Via Irnerio 48, 40136 Bologna, Italy \\ E-mail: diana@unipa.it
}

Dedicated to Professor Vincenzo Tortorella on the occasion of his "Fuori Ruolo" status (received 24 Nov 03; accepted 15 Jan 04; published on the web 15 Jan 04)

\begin{abstract}
Derivatives of the title ring system of type $\mathbf{1 0}$ were obtained in good yield by fusion of the intermediates 12. Attempt to cyclize the acetylamino derivative $\mathbf{9}$ under Bischler-Napieralski conditions failed because of the insufficient electronic density in the position 4 of the pyrazole ring created by the adjacent carbonyl moiety. The derivatives of the new ring system, assayed as anxiolytic agents, showed no significant activity.
\end{abstract}

Keywords: Pyrazole, 1,6-benzodiazocine, pyrazolo-1,6-benzodiazocine, Bischler-Napieralski, anxiolytic activity

\section{Introduction}

Since the early eighties the 1,5-benzodiazocine system has acquired remarkable importance because of its interesting analgesic, anticonvulsant, and tranquillizer activities. ${ }^{1-3}$ Also annelated benzodiazocines have shown interesting activities. Thus dibenzodiazocines showed to be effective inhibitors of the enzyme thromboxane A2 (TxA2) synthase; ${ }^{4}$ or to have intercalating capability between DNA base pairs ${ }^{5}$ whilst pyrazolo-benzodiazocines of type $\mathbf{1}$ exhibited activity on CNS. ${ }^{6}$

In connection with our researches on pyrazole-fused heterocycles with potential pharmaceutical activity we have recently synthesized derivatives of the new ring system 
dipyrazolo[3,4-b:4',3'-f] [1,5]diazocine 2. ${ }^{7}$ Unfortunately, such derivatives assayed to evidence CNS activities showed to be inactive. Continuing our studies in the same field, we became interested in the synthesis of the new ring system pyrazolo[3,4-c][1,6]benzodiazocine of type 3 , with the aim to verify whether both the replacement of the pyrazole ring with a benzene nucleus and the shift of the nitrogen of the diazocine moiety from the 5 to the 6 position would produce compounds with some CNS activity.

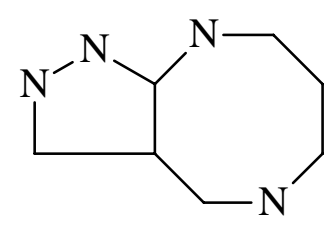

1

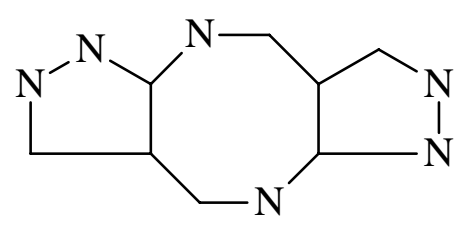

2

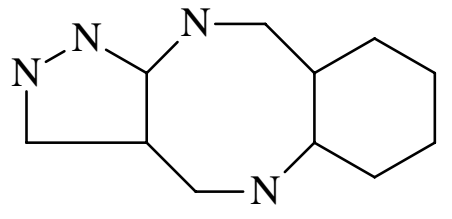

3

Figure 1

\section{Results and Discussion}

We started our synthesis reacting 5-pyrazolecarbonyl chloride 4 with the substituted 2nitroanilines 5a-c to give the corresponding 5-pyrazolecarboxamides 6a-c in acceptable yields (50-65\%). Reaction of these latter with methyl iodide in alkaline medium afforded the methyl derivatives 7a-c in good yields (70-85\%). Catalytic hydrogenation on Raney-nickel of compound 7a led to the corresponding amine derivative 8 (75\%) which was quantitatively converted into 9 by reaction with acetic anhydride.

The attempt to cyclize of the acetamido derivative $\mathbf{9}$ was carried out in refluxing phosphorous oxychloride. However under the Bischler-Napieralski reaction conditions the expected new ring system pyrazolo[3,4-c][1,6]benzodiazocine was not obtained and a very complex reaction mixture was formed from which it was only possible to isolate 1-ethyl-3-methylpyrazole 5carboxylic acid. The failure of the cyclization involving electrophilic attack on the position 4 of the pyrazole ring, has probably to be ascribed to the presence of the carbonyl group in the position 5 that decreases the electronic density on the reaction centre. In fact, in compound $\mathbf{9}$, between positions 4 and 5 of the pyrazole nucleus, there is a larger transmission of electronic effects (hyper ortho) than between the positions 3 and 4 (hypo ortho) due to the high "bond fixation" which give rise to a C-4-C-5 bond with a high $\pi$ bond order as already pointed out in pyrrole and thiophene rings. ${ }^{8,9}$

We therefore undertook a different synthetic approach to the pyrazolobenzodiazocine ring system. Thus, reaction of acetic anhydride on derivatives $7 \mathrm{led}$, in excellent yields, to the corresponding acetyl derivatives $\mathbf{1 1}$ which were reduced with stannous chloride in hydrochloric acid to the amino derivatives 12 (70-75\%). Such amino derivative heated at their melting temperatures for one hour gave the expected new tricyclic ring system pyrazolo[3,4-c][1,6] benzodiazocine in good yield (57-70\%). 
The structure of compounds 6-12 was confirmed by spectroscopic data as well as elemental analysis (see Tables 1 - 3).

In the case of compounds $\mathbf{1 1}$ and $12{ }^{1} \mathrm{H}$ NMR spectra provided evidence for the presence of a rotational isomerism because of the hindered rotation due both to the partial double bond character of the amide $\mathrm{C}-\mathrm{N}$ bond, and to the steric hindrance of the substituents in position 4 and 2'. In fact two set of signals due to $\mathrm{N}$-methyl, the pyrazole and phenyl substituents were observed. The relative abundance of the more stable conformer was $75-87 \%$. The signals belonging to both conformers are reported in Table 2.<smiles>CCn1nc(C)cc1C(=O)Cl</smiles>

4<smiles>CCn1nc(C)cc1C(=O)N(C)c1ccccc1N</smiles><smiles>CCn1nc(C)cc1C(=O)N(CC(C)=O)c1ccccc1NC(C)=O</smiles>

9<smiles>[3H][13C]([3H])([3H])[C](C)C</smiles><smiles>[R]c1ccc2c(c1)N=C(C)c1c(C)nn(CC)c1C(=O)N2C</smiles>

10a-c<smiles>[R]c1ccc(N)c([N+](=O)[O-])c1</smiles>

5a-c
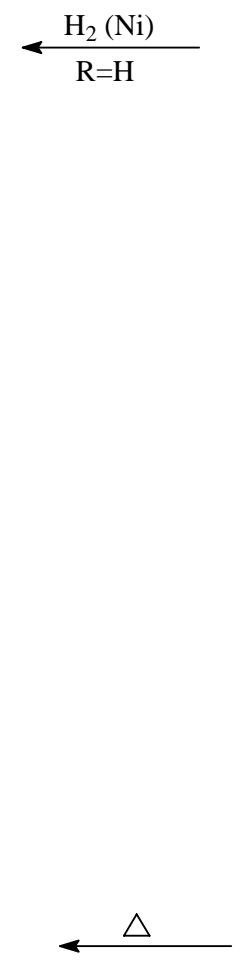

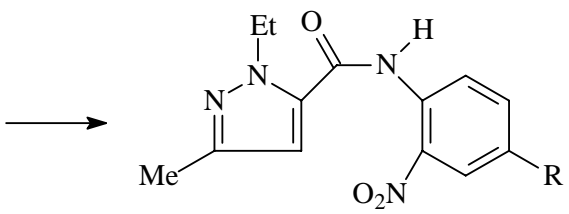

6a-c<smiles>CCC(C)C</smiles><smiles>[R]c1ccc(N(C)C(=O)c2cc(C)nn2CC)c([N+](=O)[O-])c1</smiles>

7a-c

$\mathrm{Ac}_{2} \mathrm{O} / \mathrm{H}^{+}$<smiles>[R]c1ccc(N(C)C(=O)c2c(C(C)=O)c(C)nn2CC)c([N+](=O)[O-])c1</smiles>

11a-c<smiles>[3H][AsH][14CH](Cl)Cl</smiles><smiles>[R]c1ccc(N(C)C(=O)c2c(C(C)=O)c(C)nn2CC)c(N)c1</smiles>

\section{Scheme 1}


It is interesting to note that, in compounds 11 and 12, the chemical shifts of the N-methyl signals of the predominant conformers are always upfield to the same signals related to the minor conformers. In accordance with the literature, the downfield resonance should be assigned to the conformer bearing the methyl group anti to the carbonyl. ${ }^{10}$ Therefore, in our case, the predominant conformer should be the structure A bearing the methyl syn to the carbonyl. This seems unlikely since two bulky groups would lie on the same side creating a remarkable steric hindrance. However, in our opinion, the predominant conformer is the form $\mathbf{B}$ bearing the methyl anti to the carbonyl and the unusual upfield chemical shift can be justified by the fact that the methyl protons fall inside the conical shielding region of the carbonyl anisotropic field as shown by the Figure 2 that reports the 3D-structure of the two conformers of compound 11a fully optimized in vacuo with semiempirical calculations performed with the VAMP (V 6.5) software, supplied by Oxford Molecular-Accellrys, using the Hamiltonian method PM3.

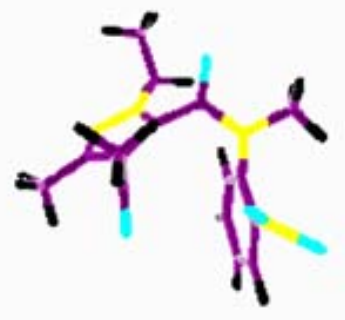

A

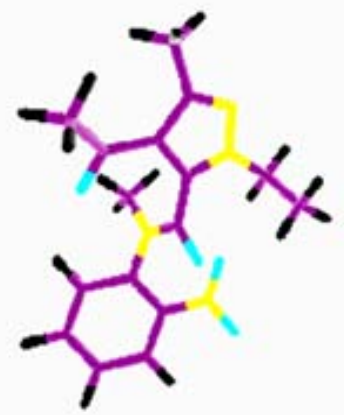

B

\section{Figure 2}

The ${ }^{1} \mathrm{H}$ and ${ }^{13} \mathrm{C}$ NMR data for the derivatives of the new ring system $\mathbf{1 0}$ are reported in Table 3. For these compounds, two different signals for the N-methylene protons were detected. This behaviour was observed in strictly correlated 1,5-diazocine series. ${ }^{7,11}$

It is interesting to note that compounds $\mathbf{1 0}$ undergo ring opening to give compounds $\mathbf{1 2}$ at room temperature upon silica gel acid catalysis.

Compounds 10 were evaluated as anxiolytic agents utilizing chlordiazepoxide as reference drug, but none of them showed significant activity.

\section{Experimental Section}

General Procedures. Melting points were measured in open capillary tubes using a BuchiTottoli immersion apparatus, and are uncorrected. The IR spectra were recorded on a PerkinElmer Infracord 137 spectrophotometer as nujol mulls. The ${ }^{1} \mathrm{H}$ NMR spectra were recorded on 
a Bruker AC 200 in deuteriochloroform solutions. TMS was used as an internal standard. Mass spectra were recorded on a JEOL JMS-Ol-SG-2 spectrometer at 75 eV(100 $\mu \mathrm{A})$.

Table 1. ${ }^{1} \mathrm{H}$ NMR chemical shifts of compounds 6-9: $\delta_{\mathrm{H}}[\mathrm{ppm}]$

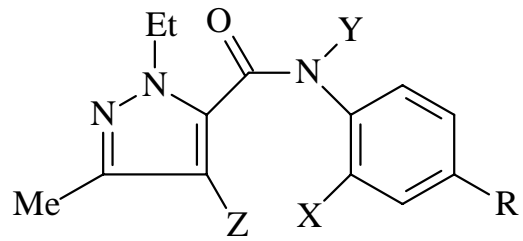

\begin{tabular}{|c|c|c|c|c|c|c|c|}
\hline Comp. & $\mathrm{N}-1-\mathrm{CH}_{2} \mathrm{CH}_{3}$ & $3-\mathrm{CH}_{3}$ & $\mathrm{Z}$ & $\mathrm{Y}$ & $X$ & $\mathrm{R}$ & Aryl-H \\
\hline \multicolumn{8}{|l|}{6} \\
\hline \multicolumn{8}{|l|}{$\mathrm{X}=\mathrm{NO}_{2}, \mathrm{Y}=\mathrm{Z}=\mathrm{H}$} \\
\hline a $\mathrm{R}=\mathrm{H}$ & $4.60,1.47$ & 2.32 & 6.60 & 11.23 & & & $7.21-8.89(4 \mathrm{H})$ \\
\hline b $\mathrm{R}=\mathrm{OCH}_{3}$ & $4.59,1.43$ & 2.33 & 6.57 & 10.87 & & 3.88 & 7.27-8.79 (3H) \\
\hline c $\mathrm{R}=\mathrm{Cl}$ & $4.51,1.37$ & 2.02 & 6.70 & 10.65 & & & $7.79-8.63(3 \mathrm{H})$ \\
\hline \multicolumn{8}{|l|}{7} \\
\hline \multicolumn{8}{|l|}{$\mathrm{X}=\mathrm{NO}_{2}, \mathrm{Y}=\mathrm{CH}_{3}, \mathrm{Z}=\mathrm{H}$} \\
\hline a $\mathrm{R}=\mathrm{H}$ & $4.32,1.44$ & 2.01 & 5.22 & 3.45 & & & $7.47-7.94(4 \mathrm{H})$ \\
\hline $\mathbf{b} \mathrm{R}=\mathrm{OCH}_{3}$ & $4.31,1.44$ & 2.04 & 5.24 & 3.39 & & 3.99 & $7.20-7.42(3 \mathrm{H})$ \\
\hline c $\mathrm{R}=\mathrm{Cl}$ & $4.30,1.44$ & 2.08 & 5.29 & 3.43 & & & $7.43-7.94(3 \mathrm{H})$ \\
\hline \multicolumn{8}{|l|}{8} \\
\hline $\begin{array}{c}\mathrm{X}=\mathrm{NH}_{2}, \mathrm{Y}=\underset{\mathrm{C}}{\mathrm{CH}_{3}, \mathrm{Z}=\mathrm{R}=\mathrm{H}} \\
\mathbf{9}\end{array}$ & $4.25,1.31$ & 1.92 & 5.57 & 3.15 & 5.35 & & $6.39-7.01(4 \mathrm{H})$ \\
\hline $\begin{array}{l}\mathrm{X}=\mathrm{NHAc}, \quad \mathrm{Y}=\quad \mathrm{CH}_{3}, \\
\mathrm{Z}=\mathrm{R}=\mathrm{H}\end{array}$ & $4.25,1.34$ & 1.69 & 5.27 & 3.20 & $9.51,2.08$ & & $7.06-7.81(4 \mathrm{H})$ \\
\hline
\end{tabular}

General procedure for the synthesis of l-ethyl-3-methyl- $N-(4$ '-R-2'-nitrophenyl)-1Hpyrazole-5-carboxamide (6a-c)

A solution of 4 (5 mmol), aniline derivatives 5 a-c $(5 \mathrm{mmol})$, and triethylamine $(5 \mathrm{mmol})$ in toluene $(50 \mathrm{~mL})$ was refluxed for $5 \mathrm{~h}$. The solvent was then evaporated under reduced pressure and the residue was recrystallized from ethanol.

Compound 6a $(\mathrm{R}=\mathrm{H})$ : yield 60\%; mp 120-121 ${ }^{\circ} \mathrm{C}$ (yellow crystals); IR: $3350(\mathrm{NH}), 1670(\mathrm{CO}) \mathrm{cm}^{-1}$. Anal. Calcd. for $\mathrm{C}_{13} \mathrm{H}_{14} \mathrm{~N}_{4} \mathrm{O}_{3}$ : C, 56.93; H, 5.15; N, 20.43. Found: C,56. 77; H, 5.35; N, 20.22.

Compound $\mathbf{6 b}\left(\mathrm{R}=\mathrm{OCH}_{3}\right)$ : yield $65 \%$; $\mathrm{mp} 135-136^{\circ} \mathrm{C}$ (orange needles); IR: $3380(\mathrm{NH}), 1680$ (CO) $\mathrm{cm}^{-1}$. Anal. Calcd. for $\mathrm{C}_{14} \mathrm{H}_{16} \mathrm{~N}_{4} \mathrm{O}_{4}$ : C, 55.25; H, 5.30; N,18.41. Found: C, 55.34, H, 5.57; $\mathrm{N}, 18.32$. 
Compound 6c $(\mathrm{R}=\mathrm{Cl})$ : yield 50\%; mp 115-116 ${ }^{\circ} \mathrm{C}$ (yellow crystals); IR: $3380(\mathrm{NH}), 1690$ (CO) $\mathrm{cm}^{-1}$. Anal. Calcd. for $\mathrm{C}_{13} \mathrm{H}_{13} \mathrm{~N}_{4} \mathrm{O}_{3} \mathrm{Cl}$ : C, 50.58; H, 4.21; N, 18.15. Found: C, 50.39; H, 4.33; N, 18.27 .

General procedure for the synthesis of l-ethyl- $N, 3-$ dimethyl- $N-(4$ '-R-2'-nitrophenyl)-1Hpyrazole-5-carboxamide (7a-c)

To the solution of compounds 6a-c (3 mmol ) in warm acetone $(10 \mathrm{~mL})$ was added powdered potassium hydroxide $(10 \mathrm{mmol})$ or sodium carbonate (in the case of $\mathbf{6 c}$ ). The mixture was gently refluxed while methyl iodide $(42 \mathrm{mmol})$ in acetone $(5 \mathrm{~mL})$ was added. After 30 minutes the solution was filtered, concentrated, diluted with water and cooled. The solid precipitate was collected, air dried and purified by flash chromatography on column of silica gel (eluant petroleum ether-ethyl acetate, 80:20)

Compound 7a $(\mathrm{R}=\mathrm{H})$ : yield $75 \%$; mp $134-135^{\circ} \mathrm{C}$ (pale yellow crystals from toluene); IR: 1640 (CO) $\mathrm{cm}^{-1}$. Anal. Calcd. for $\mathrm{C}_{14} \mathrm{H}_{16} \mathrm{~N}_{4} \mathrm{O}_{3}$ : C, 58.32; H, 5.59; N, 19.44. Found: C, 58.25; H, 5.47; $\mathrm{N}, 19.35$.

Compound $7 \mathbf{b}\left(\mathrm{R}=\mathrm{OCH}_{3}\right)$ : yield of $85 \%$; mp $62-63^{\circ} \mathrm{C}$ (pale yellow crystals from toluenepetroleum ether); IR: 1660 (CO) $\mathrm{cm}^{-1}$. Anal. Calcd. for $\mathrm{C}_{15} \mathrm{H}_{18} \mathrm{O}_{4} \mathrm{~N}_{4}$ : C, 56.59; H, 5.70; N, 17.60 . Found: C, 56.41; H, 5.65; N, 17.49 .

Compound 7c $(\mathrm{R}=\mathrm{Cl})$; yield $70 \%$; mp $103-104^{\circ} \mathrm{C}$ (pale yellow crystals from toluene); IR: 1655 (CO) $\mathrm{cm}^{-1}$. Anal. Calcd. for $\mathrm{C}_{14} \mathrm{H}_{15} \mathrm{~N}_{4} \mathrm{O}_{3} \mathrm{Cl}$ : C, 52.10; H, 4.68; N, 17.36. Found: C, 52.23; H, 4.84; N, 17.56 .

Synthesis of 1-ethyl- $N, 3$-dimethyl- $N$-(2'-aminophenyl)-lH-pyrazole-5-carboxamide (8). A mixture of 7a (3 mmol) in ethanol (50 mL) and of W-2 Raney-nickel (1 g) was hydrogenated in a Parr apparatus at 45 psi for $24 \mathrm{~h}$ at r.t. Removal of the catalyst and evaporation of the solvent under reduced pressure left the crude product which was recrystallized from ethanol (white needles).

Compound 8: yield 75\%; mp 152-153 ${ }^{\circ} \mathrm{C}$; IR: 3420, $3833\left(\mathrm{NH}_{2}\right), 1642(\mathrm{CO}) \mathrm{cm}^{-1}$. Anal. Calcd. for $\mathrm{C}_{14} \mathrm{H}_{18} \mathrm{ON}_{4}$ : C, 65.09; H, 7.02; N, 21.69. Found: C, 65.27; H, 7.18; N, 21.45.

Synthesis of l-ethyl- $N, 3$-dimethyl- $N$-(2'-acetamidophenyl)-lH-pyrazole-5-carboxamide (9). A mixture of 8 (3 mmol) and acetic anhydride $(20 \mathrm{~mL})$ was stirred at r.t. for 20 h. The reaction mixture was then poured onto crushed ice, neutralized with sodium bicarbonate and extracted with diethyl ether (2 x $60 \mathrm{~mL}$ ). The organic layers were washed with water, dried (magnesium sulfate) and evaporated under reduced pressure to dryness to give a residue which was recrystallized from ethanol (white needles).

Compound 9: yield 100\%; mp 170-171 ${ }^{\circ} \mathrm{C}$; IR: 3249 (NH), 1663,1642 (CO) cm${ }^{-1}$. Anal. Calcd. for $\mathrm{C}_{16} \mathrm{H}_{20} \mathrm{~N}_{4} \mathrm{O}_{2}$ : C, 63.98; H, 6.71; N, 18.65. Found: C, 63.77; H, 6.84; N, 18.60 . 
Table 2. ${ }^{1} \mathrm{H}$ NMR chemical shifts of compounds 11, 12: $\delta_{\mathrm{H}}$ [ppm]

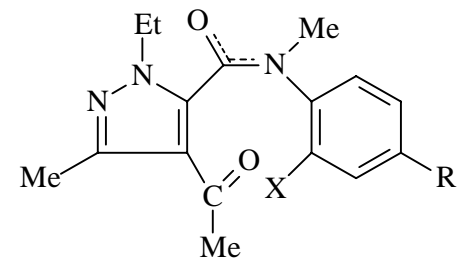

A $13-25 \%$

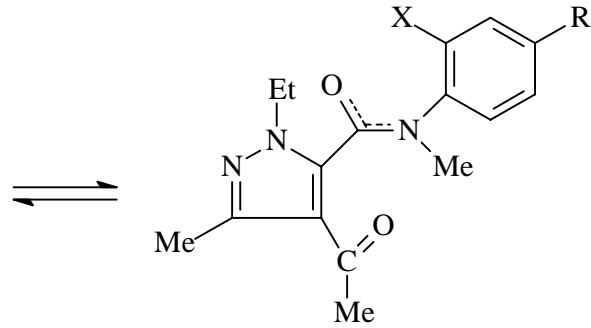

B $75-87 \%$

\begin{tabular}{|c|c|c|c|c|c|c|c|}
\hline Comp & $\mathrm{N}-1-\mathrm{CH}_{2} \mathrm{CH}_{3}$ & $3-\mathrm{CH}_{3}$ & $\mathrm{COCH}_{3}$ & $\mathrm{NCH}_{3}$ & $\mathrm{X}$ & $\mathrm{R}$ & Aryl-H \\
\hline \multicolumn{8}{|l|}{11} \\
\hline \multicolumn{8}{|l|}{$\mathrm{X}=\mathrm{NO}_{2}$} \\
\hline \multirow[t]{2}{*}{ a $\mathrm{R}=\mathrm{H}$} & $4.16,1.36(\mathbf{A})$ & $2.29(\mathbf{A})$ & $2.22(\mathbf{A})$ & 3.52 (A) & & & 7.29-8.13 \\
\hline & 4.19. 1.52 (B) & 2.56 (B) & $2.50(\mathbf{B})$ & 3.19 (B) & & & $\begin{array}{c}(4 \mathrm{H}) \\
(\mathbf{A}+\mathbf{B})\end{array}$ \\
\hline \multirow[t]{2}{*}{ b $\mathrm{R}=\mathrm{OCH}_{3}$} & $4.15,1.36$ (A) & $2.32(\mathbf{A})$ & 2.27 (A) & 3.48 (A) & & $3.82(\mathrm{~A})$ & 7.27-7.72 \\
\hline & 4.20. 1.52 (B) & $2.54(\mathbf{B})$ & 2.49 (B) & 3.15 (B) & & 3.91 (B) & $\begin{array}{c}(3 \mathrm{H}) \\
(\mathbf{A}+\mathbf{B})\end{array}$ \\
\hline \multirow[t]{2}{*}{ c $\mathrm{R}=\mathrm{Cl}$} & $3.98,1.40(\mathbf{A})$ & 2.35 (A) & $2.26(\mathrm{~A})$ & 3.49 (A) & & & 7.27-8.12 \\
\hline & 4.13. 1.55 (B) & $2.54(\mathbf{B})$ & $2.50(\mathbf{B})$ & 3.17 (B) & & & $\begin{array}{c}(3 \mathrm{H}) \\
(\mathbf{A}+\mathbf{B})\end{array}$ \\
\hline \multicolumn{8}{|l|}{12} \\
\hline \multicolumn{8}{|l|}{$\mathrm{X}=\mathrm{NH}_{2}$} \\
\hline \multirow[t]{2}{*}{ a $\mathrm{R}=\mathrm{H}$} & $4.14,1.30(\mathbf{A})$ & $2.33(\mathbf{A})$ & $2.29(\mathrm{~A})$ & 3.41 (A) & 4.80 & & $6.53-7.27$ \\
\hline & 4.20 .1 .51 (B) & $2.54(\mathbf{B})$ & $2.43(\mathbf{B})$ & 3.12 (B) & $(\mathbf{A}+\mathbf{B})$ & & $\begin{array}{c}(4 \mathrm{H}) \\
(\mathbf{A}+\mathbf{B})\end{array}$ \\
\hline \multirow[t]{2}{*}{$\mathbf{b} \mathrm{R}=\mathrm{OCH}_{3}$} & $4.07,1.30(\mathbf{A})$ & 2.35 (A) & 2.33 (A) & 3.38 (A) & 4.81 & 3.68 (A) & $6.07-7.27$ \\
\hline & 4.16. 1.49 (B) & $2.54(\mathrm{~B})$ & 2.49 (B) & 3.09 (B) & $(\mathbf{A}+\mathbf{B})$ & 3.77 (B) & $\begin{array}{c}(3 \mathrm{H}) \\
(\mathbf{A}+\mathbf{B})\end{array}$ \\
\hline \multirow[t]{2}{*}{ c $\mathrm{R}=\mathrm{Cl}$} & $4.12,1.23(\mathbf{A})$ & $2.36(\mathbf{A})$ & $2.32(\mathbf{A})$ & 3.37 (A) & 4.96 & & 6.47-7.27 \\
\hline & $4.20 .1 .50(\mathbf{B})$ & $2.54(\mathbf{B})$ & 2.49 (B) & 3.09 (B) & $(\mathbf{A}+\mathbf{B})$ & & $\begin{array}{c}(3 \mathrm{H}) \\
(\mathbf{A}+\mathbf{B})\end{array}$ \\
\hline
\end{tabular}

Reaction of phosphorus oxychloride with compound 9. A mixture of 9 (2 mmol) and phosphorus oxychloride $(30 \mathrm{~mL})$ was refluxed at $165-175^{\circ} \mathrm{C}$ for $24 \mathrm{~h}$.. The excess of phosphorus oxychloride was evaporated under reduced pressure and the mixture was poured onto crushed ice, the solution was adjusted to $\mathrm{pH} 3.5$ with solid sodium bicarbonate and extracted with chloroform $(2 \times 50 \mathrm{~mL})$. The organic layers were washed with water, dried with magnesium 
sulfate and evaporated to give a solid which was identified as 1-ethyl-3-methylpyrazole 5carboxylic acid. Subsequently, the aqueous mother liquor was adjusted to $\mathrm{pH} 8.3$ with solid sodium bicarbonate, extracted with chloroform $(2 \times 50 \mathrm{~mL})$ to give an intractable material.

Table 3. ${ }^{13} \mathrm{C}$ NMR and $\left({ }^{1} \mathrm{H}\right.$ NMR) chemical shifts of compounds 10: $\delta_{\mathrm{H}}[\mathrm{ppm}]$

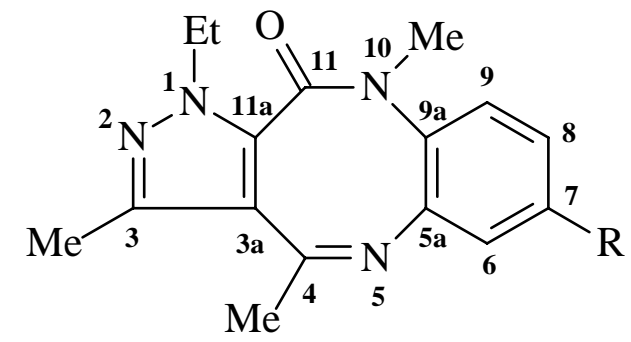

\begin{tabular}{cccc}
\hline Position & $\mathbf{a}, \mathrm{R}=\mathrm{H}$ & $\mathbf{b}, \mathrm{R}=\mathrm{OCH}_{3}$ & $\mathbf{c}, \mathrm{R}=\mathrm{Cl}$ \\
\hline 3 & 147.3 & 148.3 & 148.7 \\
$3 \mathrm{a}$ & 115.6 & 115.9 & 15.4 \\
4 & 162.0 & 162.4 & 161.8 \\
$5 \mathrm{a}$ & 133.7 & 134.7 & 134.6 \\
6 & $122.2(6.82)$ & $106.1(6.33)$ & $121.7(6.91)$ \\
7 & $124.6(7.06)$ & 158.3 & 132.1 \\
8 & $126.7(7.19)$ & $110.9(6.65)$ & $124.5(7.14)$ \\
9 & $128.0(7.35)$ & $127.6(7.27)$ & $128.6(7.44)$ \\
$9 \mathrm{a}$ & 134.8 & 127.1 & 132.8 \\
11 & 164.5 & 164.6 & 166 \\
$11 \mathrm{a}$ & 142.6 & 142.6 & $44.7(4.04 *), 12.3$ \\
$\mathrm{~N}-$ & $(1.18)$ & $44.5(4.04 *), 12.4$ & $(1.19)$ \\
$\mathrm{CH}_{2} \mathrm{CH}_{3}$ & $15.5(2.22)$ & $(1.18)$ & $15.5(2.17)$ \\
$3-\mathrm{CH}_{3}$ & $27.2(2.48)$ & $15.5(2.15)$ & $27.2(2.42)$ \\
$4-\mathrm{CH}_{3}$ & & $27.2(2.39)$ & $36.0(3.21)$ \\
$\mathrm{R}$ & $36.0(3.33)$ & $55.2(3.70)$ & $36.1(3.18)$ \\
$\mathrm{NCH}_{3}$ & $4.05 *), 12.3$ & &
\end{tabular}

* in proton spectra, recorded at $25^{\circ} \mathrm{C}$, two different resonances are detected for the methylene protons: 10a, 4.04 and 4.11 ppm; 10b, 4.04 and 4.11 ppm; 10c, 4.04 and 4.12 ppm, respectively.

General procedure for the synthesis of l-ethyl- $N, 3-$ dimethyl-4-acetyl- $N-(4$ '-R-2'nitrophenyl)-1H-pyrazole-5-carboxamide (11a-c)

A mixture of 7a-c (3 mmol), acetic anhydride $(30 \mathrm{~mL})$ and a few drops of sulfuric acid was refluxed for 6 hours. After cooling, the reaction mixture was poured into crushed ice, neutralized with solid sodium bicarbonate and extracted with ethyl ether $(2 \times 50 \mathrm{~mL})$. The organic layers were 
washed with water, dried with magnesium sulfate and concentrated to dryness under reduced pressure to give a residue which was purified by flash chromatography on column of silica gel (elution with petroleum ether(40-70)-ethyl acetate, 80:20) to give the desired products which were recrystallized from ethanol.

Compound 11a $(\mathrm{R}=\mathrm{H})$ : yield 75\%; mp 105-106 ${ }^{\circ} \mathrm{C}$ (white crystals); IR: 1660 (CO) $\mathrm{cm}^{-1}$; Anal. Calcd. for $\mathrm{C}_{16} \mathrm{H}_{18} \mathrm{~N}_{4} \mathrm{O}_{4}$ : C, 58.17; H, 5.49; N, 16.96. Found: C, 58.38; H, 5.33; N, 16.75 .

Compound 11b $\left(\mathrm{R}=\mathrm{OCH}_{3}\right)$ : yield 85\%; mp 137-138 (pale yellow crystals); IR: $1665(\mathrm{CO}) \mathrm{cm}^{-1}$. Anal. Calcd. for $\mathrm{C}_{17} \mathrm{H}_{20} \mathrm{~N}_{4} \mathrm{O}_{5}$ : C, 56.66; H, 5.59; N, 15.55. Found: C, 56.57; H, 5.41; N, 15.33.

Compound 11c $(\mathrm{R}=\mathrm{Cl})$ : yield 85\%; mp $154-155^{\circ} \mathrm{C}$ (prazel crystals); IR: $1655(\mathrm{CO}) \mathrm{cm}^{-1}$. Anal. Calcd. for $\mathrm{C}_{16} \mathrm{H}_{17} \mathrm{~N}_{4} \mathrm{O}_{4} \mathrm{Cl}$ : C, 52.68; H, 4.70; N, 15.36. Found: C,52.51; H, 4.88; N, 15.39 .

General procedure for the synthesis of 1-ethyl- $N, 3-d i m e t h y l-4$-acetyl- $N-(4$ '-R-2'aminophenyl)-1H-pyrazole-5-carboxamide (12a-c)

Compounds 11a-c (10 mmol) were added to a magnetically stirred suspension of finely powdered stannous chloride (30 mmol) in hydrochloric acid (36\%, $5 \mathrm{~mL}$ ) at such a rate so that the temperature of the slurry was maintained below $5^{\circ} \mathrm{C}$. After the complete addition of the nitro compounds, the mixture was allowed to stir for 24 hours. The white slurry thus obtained was diluted with cold water and aqueous sodium hydroxide (40\%) was added till the salts of tin were dissolved. The solution was extracted with ethyl acetate $(3 \times 50 \mathrm{~mL})$, the extracts were dried (magnesium sulphate) and evaporated under reduced pressure to give a residue which was recrystallized from ethanol.

Compound 12a $(\mathrm{R}=\mathrm{H})$ : yield $75 \%$; mp $165-166^{\circ} \mathrm{C}$ (white crystals); IR: 3446, $3362\left(\mathrm{NH}_{2}\right)$, 1654, 1640 (CO) $\mathrm{cm}^{-1}$. Anal. Calcd. for $\mathrm{C}_{16} \mathrm{H}_{20} \mathrm{~N}_{4} \mathrm{O}_{2}$ : C, 63.98; H, 6.71; N, 18.65 Found: C, 63.77; H, 6.78; N, 18.74 .

Compound 12b $\left(\mathrm{R}=\mathrm{OCH}_{3}\right)$ : yield $75 \%$; mp $140-141^{\circ} \mathrm{C}$ (pale yellow crystals); IR: 3437, 3353 $\left(\mathrm{NH}_{2}\right)$, 1656, 1634 (CO) $\mathrm{cm}^{-1}$. Anal. Calcd. for $\mathrm{C}_{17} \mathrm{H}_{22} \mathrm{~N}_{4} \mathrm{O}_{3}$ : C, 61.80; H, 6.71; N, 16.96. Found: C, 61.80; H, 6.57; N, 16.75.

Compound 12c $\left(\mathrm{R}=\mathrm{Cl}\right.$ ): yield $70 \%$; mp $194-195^{\circ} \mathrm{C}$ (yellow crystals); IR: 3443, $3354\left(\mathrm{NH}_{2}\right)$, 1655, 1635 (CO) $\mathrm{cm}^{-1}$. Anal. Calcd. for $\mathrm{C}_{16} \mathrm{H}_{19} \mathrm{~N}_{4} \mathrm{O}_{2} \mathrm{Cl}$ : C, 57.40; H, 5.72; N, 16.74. Found: C, 57.46; H, 5.89; N, 16.93.

General procedure for the synthesis of 7-R-1-ethyl-3,4,10-trimethyl-1,10-dihydro-11Hpyrazolo[3,4-c][1,6]benzodiazocin-11-ones (10 a-c)

Compounds 12a-c were heated for one hour at their melting temperature. After cooling the crude solid was recrystallized from dioxane or, in the case of $\mathbf{1 0 b}$, purified by sublimation at $165^{\circ} \mathrm{C} / 1 \mathrm{mmHg}$.

Compound 10a $(\mathrm{R}=\mathrm{H})$ : yield 57\%; mp: $100-101^{\circ} \mathrm{C}$ (white needles); IR: 1660 (CO) $\mathrm{cm}^{-1}$; ms: $\mathrm{m} / \mathrm{z} 282\left(\mathrm{M}^{+}\right)$. Anal. Calcd for $\mathrm{C}_{16} \mathrm{H}_{18} \mathrm{~N}_{4} \mathrm{O}$ : C, 68.06; H, 6.43; N, 19.85. Found: C, 68.34; H, $6.12 ; \mathrm{N}, 19.73$. 
Compound 10b $\left(\mathrm{R}=\mathrm{OCH}_{3}\right.$ ): yield 62\%, mp: 60-61 ${ }^{\circ} \mathrm{C}$ (white glassy solid); IR: $1657(\mathrm{CO}) \mathrm{cm}^{-1}$; ms: m/z $312\left(\mathrm{M}^{+}\right)$. Anal. Calcd for $\mathrm{C}_{17} \mathrm{H}_{20} \mathrm{~N}_{4} \mathrm{O}_{2}$ : C, 65.36; H, 6.45. N, 17.94. Found: C, 65.12; $\mathrm{H}$, 6.29; N, 17.74 .

Compound 10c $(\mathrm{R}=\mathrm{Cl})$ : yield $70 \%$; mp: $108-109^{\circ} \mathrm{C}$ (white crystals); IR: 1657 (CO) $\mathrm{cm}^{-1}$; ms: m/z $316\left(\mathrm{M}^{+}\right)$. Anal. Calcd. for $\mathrm{C}_{16} \mathrm{H}_{17} \mathrm{~N}_{4} \mathrm{OCl}$ : C, 60.66; H, 5.41; N, 17.69. Found: C, 60.49; H, 5.35; N, 17.82 .

\section{Acknowledgements}

This work was in part financed by MIUR (Rome).

\section{References}

1. Bogatskii, A. V.; Andronati, S. A. Khim.-Farm. Zh. 1980, 14, 45.

2. Vorovina, T. A.; Andronati, S. A. Vestn. Akad. Med. Nauk. SSSR 1984, 13.

3. Milkowski, W.; Liepmann, H. Eur. J. Med. Chem.-Chim. Ther. 1985, 20, 345.

4. Johnson, R. A.; Gorman, R. R.; Wnuk, R. J.; Crittenden, N. J.; Aiken, J. W. J. Med. Chem. 1993, 36, 3202.

5. Baldeyrou, B.; Tardy, C.; Bailly, C.; Colson, P.; Houssier, C.; Charmantray, F.; Demeunynck, M. Eur. J. Med. Chem. 2002, 37, 315.

6. De Vald, H. A.; L’Italien, Y. Ger. Offen. 2,423, 1974; Chem. Abstr. 1975, 83, 206345.

7. Migliara, O.; Lamartina, L.; Timonieri, M.; Plescia, S. J. Heterocycl. Chem. 1995, 32, 835.

8. Dattolo, G.; Cirrincione, G.; Almerico, A. M.; Presti, G.; Aiello, E. Heterocycles 1984, 22, 2269.

9. Consiglio, G.; Spinelli, D.; Gronowitz, S.; Hornfeldt, A. B.; Noto, R. Chimica Scripta 1982, 19, 46.

10. Cirrincione, G.; Hinz, W.; Jones, R. A. J. Chem. Soc., Perkin II 1984, 1089.

11. Migliara, O.; Lamartina, L.; Rainieri, R. J. Heterocycl. Chem. 1995, 32, 1589. 